\title{
Telehealth and Telemedicine in Response to Critical Coronavirus: A Systematic Review
}

\author{
Reza Safdari ${ }^{1}$, Marsa Gholamzadeh², Sorayya Rezayi², Mozhgan Tanhapour ${ }^{2}$ and Soheila Saeedi ${ }^{2, *}$ \\ 1 Department of Health Information Management, School of Allied Medical Sciences, Tehran University of Medical Sciences, Tehran, Iran \\ 2 PhD Student of Medical Informatics, Health Information Management Department, School of Allied Medical Sciences, Tehran University of Medical Sciences, \\ Tehran, Iran
}

* Corresponding author: Soheila Saeedi, Department of Health Information Management, School of Allied Medical Sciences, Tehran University of Medical Sciences, Tehran, Iran. Tel: +982188982782; Email: saeedi_s@razi.tums.ac.ir, soheila.saeedi2021@gmail.com

Received 2021 May 19; Revised 2021 June 26; Accepted 2021 August 09.

\begin{abstract}
Background: Due to the outbreak of coronavirus disease 2019 (COVID-19), applying telehealth and telemedicine to prevent the spread of the disease is inevitable.

Objectives: Therefore, this study aimed to investigate the application of telehealth and telemedicine in the human coronavirus epidemic. Methods: The systematic search was conducted using Medline (through PubMed), Scopus, and ISI Web of Science to identify relevant studies published until June 10, 2020. The inclusion criteria were the usage of telemedicine and telehealth as healthcare services during COVID-19, severe acute respiratory syndrome (SARS), or Middle East respiratory syndrome epidemics. This review was performed according to the guidelines of Preferred Reporting Items for Systematic Reviews and Meta-Analyses.

Results: In total, 598 articles were identified after the removal of the duplicates. After the systematic screening, 18 studies met the inclusion criteria. The analysis showed that only one study was related to SARS, and the rest were on COVID-19 disease. Teleconsultation and televisit were more prevalent (55.6\%) than the other types of telemedicine services. The most mentioned obstacles were access to suitable technologies and lack of assessment or follow-up to achieve outcomes.

Conclusion: The results indicated that telehealth and telemedicine could have advantages, such as prevention of the spread of COVID-19, reduction of the healthcare burden, and maintenance of appropriate patient care. In addition to these benefits, several limitations and obstacles, including organizational, technological, and patient-related barriers, may be encountered. Hence, it is better to consider the necessary arrangements before implementing telemedicine.
\end{abstract}

Keywords: Coronavirus infections, COVID-19, SARS Virus, Telehealth, Telemedicine

\section{Background}

Coronaviruses are a group of enveloped viruses with a non-segmented, linear, single-stranded, and positive ribonucleic acid genome. Coronaviruses are divided into four main categories, namely alpha, beta, gamma, and delta. Seven coronaviruses can infect humans and lead to respiratory diseases: 1 . HCoV- 229E, 2. HCoV-NL63, 3. HCoV-OC43, 4. HCoVHKU1, 5. The Middle East Respiratory Syndrome coronavirus (MERS- CoV), 6. severe acute respiratory syndrome coronavirus (SARS- CoV), and 7. coronavirus disease 2019 (COVID-19). Among different types of coronaviruses, SARS-CoV-2 is a highly pathogenic coronavirus that can be a substantial threat to public health and lead to regional or global outbreaks (1-3).

The SARS-CoV was a severe respiratory disease that became an epidemic in 2002-2003. The death rate of this coronavirus was nearly $10 \%(4,5)$. Besides, MERS-CoV is one of the seven known human coronavirus diseases and has a mortality rate of more than $35 \%$ (6). This infection has been reported in more than 27 countries in the Middle East, Europe, Asia, and North Africa (6). The COVID19 was first identified in December 2019 in Wuhan,
China. Due to the high prevalence of this disease, on March 11, 2020, it was recognized as a global epidemic (7,8). As of May 15, 2021, 162,945,289 cases have been confirmed worldwide with $3,378,017$ deaths (9).

Nowadays, COVID-19 is a global issue and a highly contagious disease. In such diseases, close contact with patients and droplets are the most common routes of transmission (10). To prevent the spread of the disease, people should avoid contact with each other as much as possible.

In this regard, it seems that the application of telehealth and telemedicine could be considered a good solution to prevent person-to-person contact, and thereby reduce the risk of contamination. Telemedicine can increase safe access to routine healthcare services without the risk of exposure and can help remote assessment of the patients (11).

Telehealth and telemedicine can meet the basic needs of patients and healthcare providers during epidemics, especially when patients are in quarantine as they can address their health problems with a phone call. Several studies have been published regarding the use of telehealth and telemedicine in epidemics $(12,13)$.

Given the importance of facilitating access to

Copyright (c) 2021, Author(s). This is an open-access article distributed under the terms of the Creative Commons Attribution-NonCommercial 4.0 International License (http://creativecommons.org/licenses/by-nc/4.0/) which permits copy and redistribute the material just in noncommercial usages, provided the original work is properly cited 
healthcare services during an epidemic, it seems essential to conduct research on the services that can be provided for patients using this technology and the obstacles in the way of telemedicine and telehealth implementation during epidemics.

\section{Objectives}

This study aimed to systematically review the use of telemedicine and telehealth during the epidemics and identify the obstacles and problems facing this technology.

The specific research objectives of this review are:

1) Representing a summary of published studies and their characteristics

2) Identification of the types of human coronavirus diseases of the patients that have received telemedicine and telehealth services

3) Categorization of the types of provided services to patients by telehealth and telemedicine

4) Determination of the utilizing duration of the services

5) Identification of the obstacles in using telemedicine and telehealth

6) Investigation of the outcomes mentioned in the studies for the application of telemedicine technology in the management of coronavirus diseases

\section{Methods}

The present study was performed following Preferred Reporting Items for Systematic Reviews and Meta-Analyses (PRISMA) proposed by Moher et al. (14) to ensure the inclusion of relevant studies.

\subsection{Literature search}

A systematic search was performed in the databases of Medline (through PubMed), Scopus, and ISI Web of Science to identify relevant studies published until June 10, 2020. The search strategy included a combination of keywords and MeSH terms related to critical coronavirus respiratory syndromes (SARS, MERS, and COVID19), telehealth, and telemedicine. A complete list of keywords is presented in Table 1.

\subsection{Eligibility criteria}

Studies were included if they met all the following inclusion criteria: 1) a focus on telemedicine and telehealth; 2) a study population consisting of people who need care services related to COVID-19, SARS, or MERS during the respective epidemics; 3) being journal articles and proceedings. On the other hand, the exclusion criteria were: 1) type of publication other than journal articles and proceedings (e.g., books, review papers, and letters); 2) lack of availability of the full text in the English language; 3 ) lack of relation of the title, abstract, or full text of the papers to COVID-19, SARS, or MERS.

\subsection{Data extraction}

To evaluate the inclusion and exclusion criteria, all titles and abstracts of papers were reviewed by three reviewers (S.R., M.G., and M.T.) who have an academic degree in Medical Informatics. Some articles were randomly reviewed by another reviewer (S.S.). The full texts of the remaining articles were reviewed by four reviewers and any disagreement between the reviewers was resolved by R.S. The following data were extracted from the included studies: names of authors, year of publication, country, journal/conference name, disease, type of telehealth, kind of services,

\begin{tabular}{|c|c|}
\hline Database & Search strategy \\
\hline PubMed & 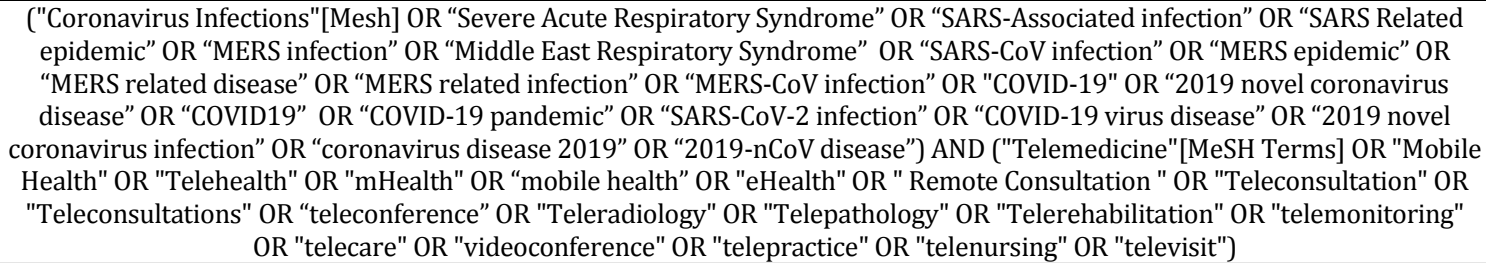 \\
\hline $\begin{array}{l}\text { Web of } \\
\text { Science }\end{array}$ & 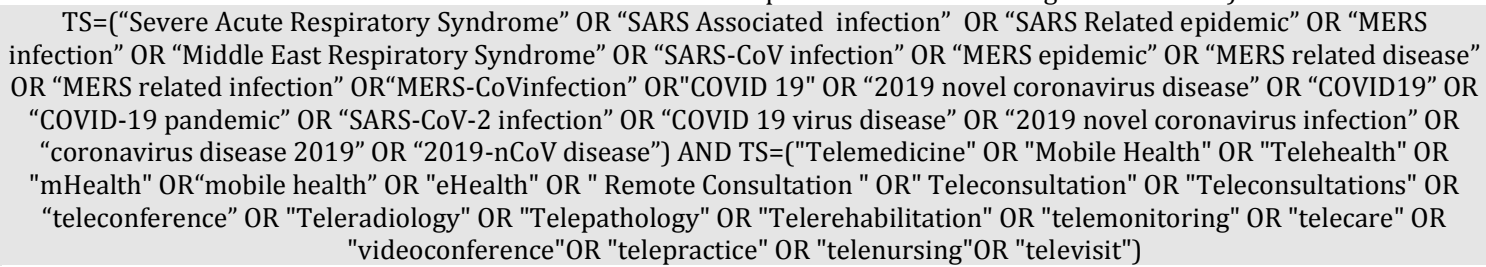 \\
\hline Scopus & $\begin{array}{l}\text { TITLE-ABS-KEY ("Severe Acute Respiratory Syndrome" OR "SARS Associated infection"OR"SARS Related epidemic" OR } \\
\text { "MERS infection" OR "Middle East Respiratory Syndrome" OR "SARS-CoV infection" OR"MERS epidemic" OR "MERS related } \\
\text { disease" OR "MERS related infection"OR"MERS-CoV infection"OR"COVID-19" OR "2019 novel coronavirus disease"OR } \\
\text { "COVID19" OR "COVID-19 pandemic" OR "SARS-CoV-2 infection"OR"COVID-19 virus disease"OR"2019 novel coronavirus } \\
\text { infection"OR "coronavirus disease 2019" OR "2019-nCoV disease") AND ("Telemedicine" OR "Mobile Health" OR } \\
\text { "Telehealth" OR "mHealth"OR "mobile health" OR "eHealth" OR " Remote Consultation"OR "Teleconsultation" OR } \\
\text { "Teleconsultations"OR "teleconference" OR "Teleradiology"OR"Telepathology"OR"Telerehabilitation"OR "telemonitoring" } \\
\text { OR "telecare" OR "videoconference"OR "telepractice" OR "telenursing" OR"televisit")) }\end{array}$ \\
\hline
\end{tabular}


obstacles of the applied approach, duration of applied approach, target population, population size, and outcome. It should be mentioned that these data were imported into a spreadsheet in Excel.

\subsection{Data analysis}

Due to the variety of services provided by telemedicine and the diversity of reported outcomes, the results were reported in the form of a narrative synthesis of evidence. Limitations and obstacles of telemedicine were also divided into four categories, including study limitations, organizational obstacles, technological obstacles, and patient-related obstacles.

\section{Results}

\subsection{Results of article search}

The process of identifying and selecting the studies based on the PRISMA diagram is shown in Figure 1. In total, 699 documents were initially retrieved through scientific database searching, 101 of which were duplicates. Among the retrieved articles, 522 documents were excluded after the title and abstract screening. Finally, 18 eligible articles were found through this review. To represent the frequency of keywords in reviewed articles, the cooccurrence of terms among the titles and abstracts was found using the VOSviewer software (version 1.6.16) in Figure 2.
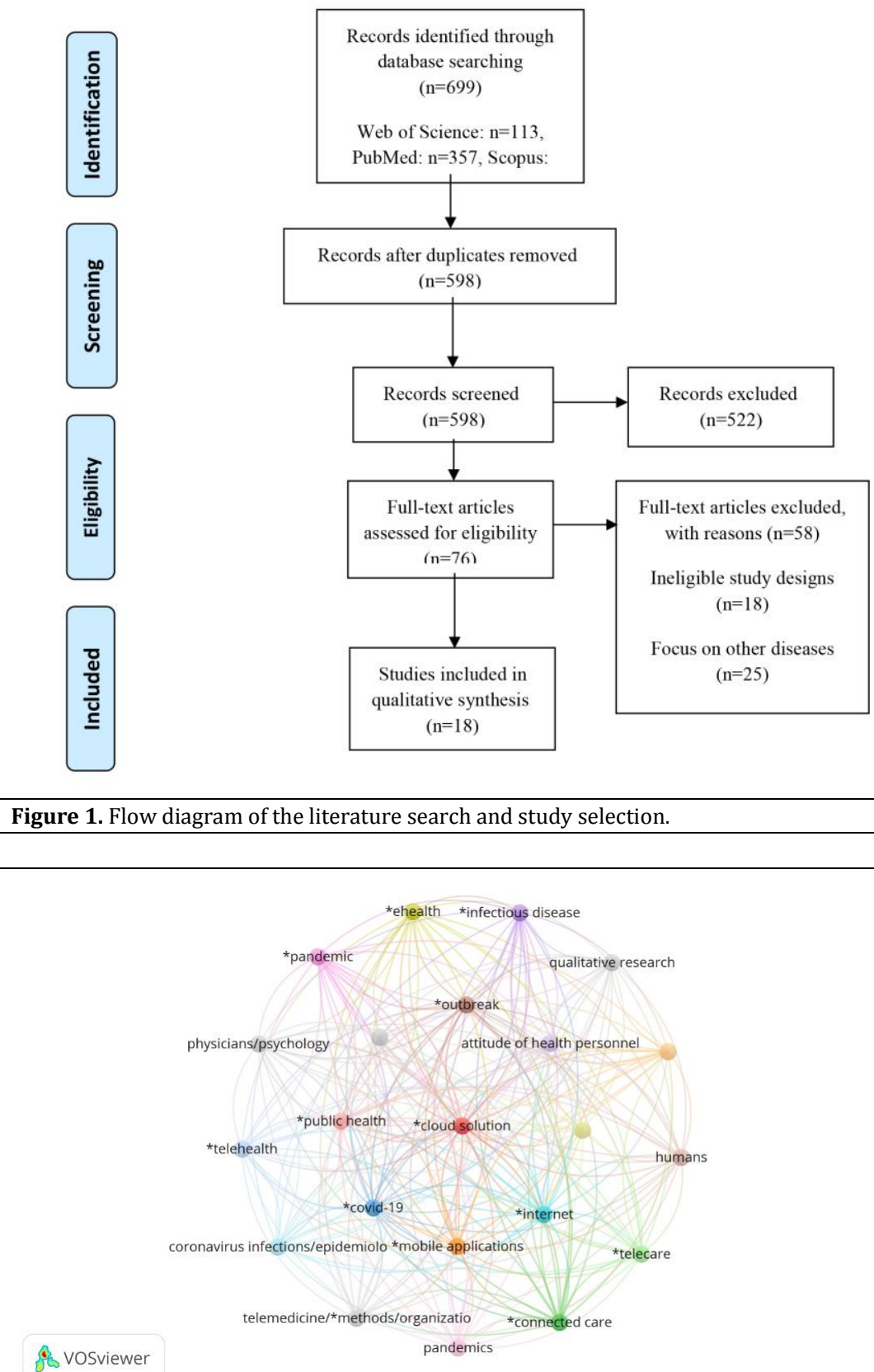

Figure 2. Keyword co-occurrence from VOSviewer software. 


\begin{tabular}{|c|c|c|c|c|c|c|c|c|c|}
\hline$\#$ & Author & $\begin{array}{l}\text { Journal/Confere } \\
\text { nce name }\end{array}$ & Disease & $\begin{array}{c}\text { Type of } \\
\text { telehealth }\end{array}$ & Kind of service & $\begin{array}{l}\text { Period of } \\
\text { the applied } \\
\text { approach }\end{array}$ & $\begin{array}{c}\text { Target } \\
\text { population }\end{array}$ & $\begin{array}{l}\text { Population } \\
\text { size }\end{array}$ & Outcome \\
\hline 1 & $\begin{array}{l}\text { Timmers T. et al. } \\
(25), 2020 \\
\text { Netherlands }\end{array}$ & $\begin{array}{l}\text { JMIR Mhealth } \\
\text { Uhealth }\end{array}$ & COVID-19 & Real-time & $\begin{array}{l}\text { Tele-education } \\
\text { and mobile } \\
\text { health }\end{array}$ & 7 days & Screened patients & 6,194 & $\begin{array}{l}\text { The collected data could be used to } \\
\text { support policymakers and healthcare } \\
\text { providers to obtain valuable insights into the } \\
\text { regional distribution of infection load and } \\
\text { healthcare consumption. }\end{array}$ \\
\hline 2 & $\begin{array}{l}\text { Jethwa T. et al. } \\
(26), 2020 \text {, USA }\end{array}$ & $\begin{array}{l}\text { Telemedicine and } \\
\text { e-Health }\end{array}$ & COVID-19 & Real-time & Televisit & $\begin{array}{l}\text { Until } \\
\text { symptoms } \\
\text { improve }\end{array}$ & Screened patients & 63 & $\begin{array}{l}\text { The virtual clinic allows researchers to } \\
\text { provide high-quality care during anxious } \\
\text { times without consuming excessive personal } \\
\text { protective equipment or unnecessarily } \\
\text { exposing healthcare workers. }\end{array}$ \\
\hline 3 & $\begin{array}{l}\text { Rabunal R. et al. } \\
\text { (27), 2020, } \\
\text { Spain }\end{array}$ & $\begin{array}{l}\text { Telemedicine and } \\
\text { e-Health }\end{array}$ & COVID-19 & $\begin{array}{l}\text { Store and } \\
\text { forward }\end{array}$ & Telemonitoring & 14 days & CoviD-19 patient & 275 & $\begin{array}{l}\text { The telemedicine tool (TELEA) is useful for } \\
\text { the management of high-risk patients with } \\
\text { COVID-19. }\end{array}$ \\
\hline 4 & $\begin{array}{l}\text { Denis F. et al. } \\
(21), 2020 \\
\text { France }\end{array}$ & $\begin{array}{l}\text { Journal Of Medical } \\
\text { Internet Research }\end{array}$ & COVID-19 & $\begin{array}{l}\text { Real- } \\
\text { time/store } \\
\text { and } \\
\text { forward }\end{array}$ & Teleconsultation & No period & $\begin{array}{c}\text { General } \\
\text { population }\end{array}$ & $3,799,535$ & $\begin{array}{l}\text { This study suggests that self-reported } \\
\text { symptoms of COVID- } 19 \text { are correlated with } \\
\text { COVID-19-related hospitalizations and that } \\
\text { anosmia may be strongly associated with } \\
\text { COVID-19 }\end{array}$ \\
\hline 5 & $\begin{array}{c}\text { Tran D. et al. } \\
(28), 2020, \text { USA }\end{array}$ & $\begin{array}{l}\text { Journal of Pain } \\
\text { and Symptom } \\
\text { Management }\end{array}$ & COVID-19 & Real-time & Televisit & 3 months & $\begin{array}{l}\text { Screened patients } \\
\text { and the general } \\
\text { population }\end{array}$ & $\begin{array}{c}\text { Not } \\
\text { mentioned }\end{array}$ & $\begin{array}{l}\text { This approach is effective in conserving } \\
\text { important resources and minimizing the risk } \\
\text { of infection between patients and palliative } \\
\text { care team members. }\end{array}$ \\
\hline 6 & $\begin{array}{l}\text { Evans KD. et al. } \\
\text { (24), 2020, } \\
\text { china }\end{array}$ & $\begin{array}{l}\text { Journal of } \\
\text { Diagnostic } \\
\text { Medical } \\
\text { Sonography }\end{array}$ & COVID-19 & $\begin{array}{l}\text { Store and } \\
\text { forward }\end{array}$ & Telediagnosis & $\begin{array}{c}\text { Not } \\
\text { mentioned }\end{array}$ & Screened patients & 2 & $\begin{array}{l}\text { There is great potential for reducing the } \\
\text { exposure of patients to ionizing radiation } \\
\text { while limiting the spread of disease through } \\
\text { patient transport and intervention provision. }\end{array}$ \\
\hline 7 & $\begin{array}{l}\text { Zhang J. et al. } \\
\text { (29), 2003, } \\
\text { china }\end{array}$ & $\begin{array}{l}\text { Computerized } \\
\text { Medical Imaging } \\
\text { and Graphics }\end{array}$ & SARS & Real-time & Teleconsultation & 1 month & SARS patients & 8 & $\begin{array}{l}\text { Radiologists and off-site experts did not have } \\
\text { to be concerned with SARS infection. } \\
\text { Moreover, the central collaborative operation } \\
\text { mode simplified the consultation procedures } \\
\text { in the image and medical record delivery and } \\
\text { display, compared to the point-to-point model }\end{array}$ \\
\hline 8 & $\begin{array}{l}\text { Schinkothe, T, et } \\
\text { al. (30), 2020, } \\
\text { Argentina }\end{array}$ & $\begin{array}{l}\text { IMIR Public } \\
\text { Health and } \\
\text { Surveillance }\end{array}$ & COVID-19 & Real-time & $\begin{array}{l}\text { Televisit and } \\
\text { telemonitoring }\end{array}$ & $\begin{array}{c}\text { Not } \\
\text { mentioned }\end{array}$ & $\begin{array}{l}\text { Patients with } \\
\text { chronic diseases } \\
\text { and COVID-19 } \\
\text { patient }\end{array}$ & $\begin{array}{c}\text { Not } \\
\text { mentioned }\end{array}$ & $\begin{array}{l}\text { The C19CC demonstrates how eHealth } \\
\text { technology can quickly adapt to actual } \\
\text { changing needs in the healthcare } \\
\text { environment, aid healthcare personnel in } \\
\text { inpatient care, and ensure patient safety at the } \\
\text { same time. }\end{array}$ \\
\hline 9 & $\begin{array}{l}\text { Krausz, M. et al. } \\
\text { (31), 2020, } \\
\text { Canada }\end{array}$ & $\begin{array}{l}\text { IMIR Public } \\
\text { Health and } \\
\text { Surveillance }\end{array}$ & COVID-19 & Real-time & $\begin{array}{l}\text { Televisit and } \\
\text { telemonitoring }\end{array}$ & $\begin{array}{l}\text { As of March } \\
23,2020\end{array}$ & COVID-19 patient & 13,479 & $\begin{array}{c}\text { Web-based solutions have the potential to fill } \\
\text { an urgent gap in resource allocation by } \\
\text { becoming a unique asset for health systems } \\
\text { governance and management during critical } \\
\text { times. }\end{array}$ \\
\hline 10 & $\begin{array}{l}\text { Annis, T, et al. } \\
(17), 2020, \text { USA }\end{array}$ & $\begin{array}{l}\text { Journal of the } \\
\text { American Medical } \\
\text { Informatics } \\
\text { Association }\end{array}$ & COVID-19 & Real-time & Telemonitoring & 34 days & COVID-19 patient & 3,701 & $\begin{array}{l}\text { This program provided a safe and satisfying } \\
\text { experience for patients while minimizing } \\
\text { COVID-19 exposure and in-person healthcare } \\
\text { utilization. }\end{array}$ \\
\hline 11 & $\begin{array}{l}\text { Smith, W. R, et } \\
\text { al. (32), 2020, } \\
\text { USA }\end{array}$ & $\begin{array}{l}\text { Journal of the } \\
\text { American College } \\
\text { of Surgeons }\end{array}$ & COVID-19 & Real-time & televisit & 1 month & Outpatient visits & $\begin{array}{c}\text { Not } \\
\text { mentioned }\end{array}$ & $\begin{array}{l}\text { This practical guide should facilitate the } \\
\text { transition to a telemedicine program. It can } \\
\text { serve as an effective resource for staff and } \\
\text { provider training. }\end{array}$ \\
\hline 12 & $\begin{array}{l}\text { Meinert, E. et al. } \\
(15), 2020, \text { UK }\end{array}$ & $\begin{array}{l}\text { IMIR Public } \\
\text { Health and } \\
\text { Surveillance }\end{array}$ & COVID-19 & Real-time & Telemonitoring & 12 month & $\begin{array}{l}\text { Older people and } \\
\text { their family }\end{array}$ & 27,450 & $\begin{array}{l}\text { This case study enables operational decision } \\
\text { support for logistical placement, resource } \\
\text { assignment, and management to combat } \\
\text { mental and societal issues arising from social } \\
\text { distancing measures. }\end{array}$ \\
\hline 13 & $\begin{array}{l}\text { Bonavita, S (23). } \\
\text { et al., 2020, not } \\
\text { mentioned }\end{array}$ & $\begin{array}{l}\text { Neurological } \\
\text { Sciences }\end{array}$ & COVID-19 & Real-time & Telemonitoring & $\begin{array}{c}\text { Not } \\
\text { mentioned }\end{array}$ & $\begin{array}{l}\text { People with } \\
\text { multiple sclerosis }\end{array}$ & $\begin{array}{c}\text { Not } \\
\text { mentioned }\end{array}$ & $\begin{array}{l}\text { Patient-centric care using digital triage may } \\
\text { decrease the burden on health facilities while } \\
\text { enabling ongoing individualized surveillance } \\
\text { and healthcare provision and limiting } \\
\text { unnecessary access to the MS centers which } \\
\text { reduces the risk of spreading the infection. }\end{array}$ \\
\hline 14 & $\begin{array}{l}\text { Borchert, A. et } \\
\text { al. (18), 2020, } \\
\text { USA }\end{array}$ & Urology & COVID-19 & Real-time & Teleconsultation & 21 days & $\begin{array}{l}\text { Inpatient urology } \\
\text { consultations }\end{array}$ & 53 & $\begin{array}{l}\text { This pathway reduces the transmission risk to } \\
\text { both healthcare providers and patients, } \\
\text { reduces the healthcare burden, and maintains } \\
\text { appropriate patient care. }\end{array}$ \\
\hline 15 & $\begin{array}{l}\text { Blackhall, K. K.et } \\
\text { al. (20), 2020, } \\
\text { UK }\end{array}$ & $\begin{array}{l}\text { British Journal of } \\
\text { Oral and } \\
\text { Maxillofacial } \\
\text { Surgery }\end{array}$ & COVID-19 & Real-time & Teleconsultation & 42 days & $\begin{array}{l}\text { Oral and } \\
\text { Maxillofacial } \\
\text { Surgery } \\
\text { departments' } \\
\text { patients }\end{array}$ & 529 & $\begin{array}{l}\text { Telemedicine would alleviate the undue } \\
\text { pressure on the stakeholders of the dental } \\
\text { service. The significant reduction in the } \\
\text { emergency workload may allow for members } \\
\text { to be redeployed to other duties in the } \\
\text { hospital }\end{array}$ \\
\hline 16 & $\begin{array}{l}\text { Grange. E et al. } \\
(33), 2020 \text {, USA }\end{array}$ & $\begin{array}{l}\text { J Pain Symptom } \\
\text { Manage }\end{array}$ & COVID-19 & Real-time & Televisit & $\begin{array}{l}\text { Since the } \\
\text { emergence } \\
\text { of pandemic }\end{array}$ & Clinic patients & $\begin{array}{c}\text { Not } \\
\text { mentioned }\end{array}$ & $\begin{array}{l}\text { University of Washington School of Medicine } \\
\text { pivoted quickly to address clinical needs as } \\
\text { they arose with COVID-19. They had a larger } \\
\text { supply of equipment on hand to support both } \\
\text { teleworking and telemedicine. }\end{array}$ \\
\hline 17 & $\begin{array}{l}\text { Khairat.S et al. } \\
(34), 2020 \text {, USA }\end{array}$ & $\begin{array}{l}\text { JMIR Public } \\
\text { Health Surveill }\end{array}$ & COVID-19 & Real-time & Televisit & 1 month & $\begin{array}{l}\text { Covid-19 like } \\
\text { symptoms }\end{array}$ & $\begin{array}{l}825 \text { virtual } \\
\text { visits }\end{array}$ & $\begin{array}{l}\text { This study showed that virtual care can } \\
\text { prevent emergency visits, protect healthcare } \\
\text { resources, and prevent the spread of COVID- } \\
19 \text { by remote access to patients. }\end{array}$ \\
\hline 18 & $\begin{array}{l}\text { Gong.K et al. } \\
\text { (35), 2020, } \\
\text { China }\end{array}$ & J Med Internet Res & COVID-19 & Real-time & Teleconsultation & 1 month & $\begin{array}{l}\text { Positive } \\
\text { hypochondriacal } \\
\text { suspicion }\end{array}$ & $\begin{array}{c}8913 \\
\text { consultations }\end{array}$ & $\begin{array}{l}\text { The results showed that the epidemic of } \\
\text { COVID- } 19 \text { brought panic and hypochondria to } \\
\text { the public, further inducing improper health- } \\
\text { seeking behaviors and increased demand for } \\
\text { medical care services. }\end{array}$ \\
\hline
\end{tabular}

\subsection{General characteristics of the included studies}

The general and main characteristics of the included studies are summarized in Table 2. The analysis showed that all of the included articles were published in 2020, and only one article was published in 2003 (about SARS disease). Regarding publication, the 
eligible studies were published in 14 different journals. The "JMIR Public Health and Surveillance" had the first rank among the journals with four studies. Most of the studies $(7,39 \%)$ were conducted in the USA, three in China, two in the UK, and one in Argentina, Canada, France, Netherlands, Italy, and Spain. The sample size was not mentioned in five studies, and that of the other studies ranged from 2 to 3,799,535 participants.

4.3. The distribution of literature by type of disease

The analysis showed that $94 \%$ of the included studies were about COVID-19. Only one study was performed about SARS disease and telemedicine, while no study was performed on MERS.

\subsection{Telemedicine service}

All of the articles were classified into six categories based on the telemedicine type. It was found that teleconsultation and televisit were more prevalent $(55.6 \%)$ than other types (Table 3). All telemedicine services can be categorized into the store, forward, and real-time based on their provided services. The distribution of papers according to the type of services and telemedicine type is represented in Figure. 3.

\begin{tabular}{lcc}
\hline Table 3. Types of applied service & & \\
\hline Type of intervention & Frequency & Percentage \\
\hline Teleconsultation & 5 & $27.8 \%$ \\
Televisit & 5 & $27.8 \%$ \\
Telemonitoring & 4 & $22.2 \%$ \\
Televisit and telemonitoring & 2 & $11.1 \%$ \\
Tele-education and mobile health & 1 & $5.6 \%$ \\
Telediagnosis & 1 & $5.6 \%$ \\
\hline
\end{tabular}

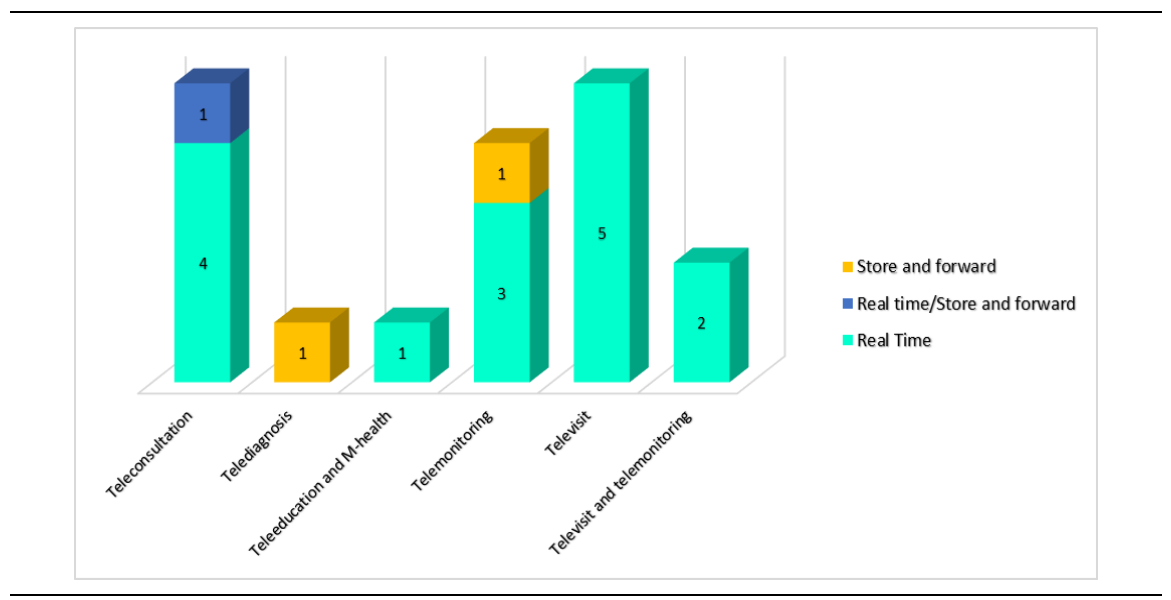

Figure 3. Distribution of papers according to the type of service and telemedicine.

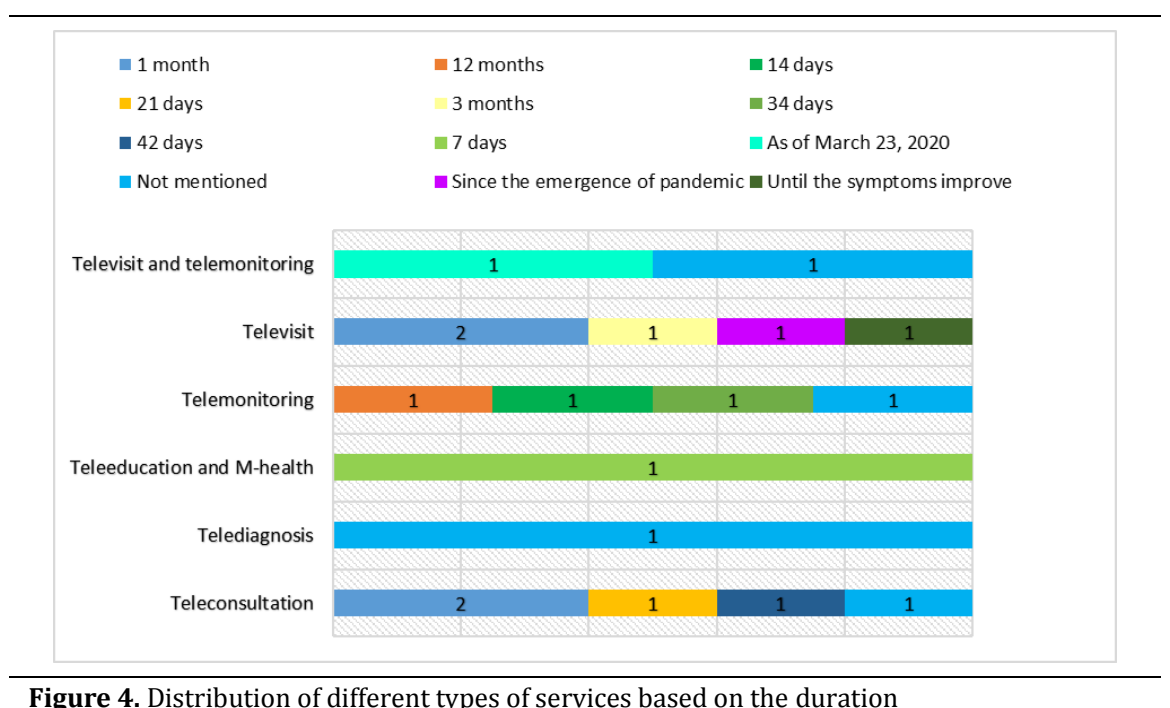

Figure 4. Distribution of different types of services based on the duration

4.5. The distribution of studies by duration and type of telemedicine service

Several types of telemedicine services were used to control the disease for a specific period. The distribution of different types of services is shown based on the duration used in Figure 4. 


\begin{tabular}{|c|c|}
\hline Obstacles category & Obstacles \\
\hline Study limitations & 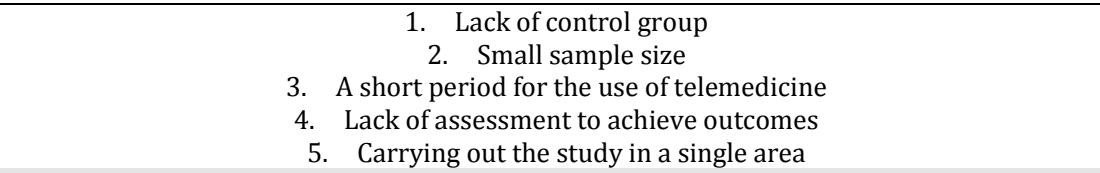 \\
\hline Technological obstacles & $\begin{array}{l}\text { 1. Weak internet connections } \\
\text { 2. Bandwidth limitations } \\
\text { 3. Software and hardware limitations } \\
\text { 4. Cybersecurity }\end{array}$ \\
\hline Management obstacles & $\begin{array}{l}\text { 1. Ethical issues } \\
\text { 2. Licenses } \\
\text { 3. Standards }\end{array}$ \\
\hline Patients related obstacles & $\begin{array}{l}\text { 1. Patient privacy } \\
\text { 2. Inability of some users to use the equipment, such as applications } \\
\text { 3. Lack of information, such as physical and auxiliary examinations } \\
\text { 4. Lack of access to some equipment } \\
5 \text {. Lack of follow-up }\end{array}$ \\
\hline
\end{tabular}

\subsection{The obstacles and outcomes of reviewed studies}

Limitations and obstacles mentioned in the studies were classified into four main categories, including study limitations, technological obstacles, organizational obstacles, and patient-related obstacles (Table 4). The results demonstrated that telemedicine intervention could prevent the spread of COVID-19, reduce the transmission risk to healthcare providers and patients, reduce the healthcare burden, and maintain appropriate patient care but proving this evidence requires further research and study.

\section{Discussion}

The COVID-19 pandemic has caused a significant increase in outpatient visits. In addition, it has impacted routine care; therefore, changes have been made to the way people receive routine care. Telemedicine is one of the best solutions that have been considered by healthcare providers during this pandemic $(15,16)$. This strategy could improve the safety of healthcare providers, reduce the risk of COVID-19 exposure for patients and physicians, and decrease in-person healthcare utilization $(17,18)$. This paper aimed to identify and analyze various telemedicine techniques used to manage and control the human coronavirus epidemic. The analysis showed that there is an increasing tendency among researchers to use telemedicine and telehealth services during the COVID-19 pandemic.

The analysis also revealed that most of the reviewed studies were devoted to teleconsultation, telemonitoring, and televisit techniques for patients with coronavirus. Since the main problem of a pandemic is routine care delivery, this result is reasonable (19) Besides, telemedicine techniques, teleconsultation, and telemonitoring provide the opportunity for self-management and continuous care for patients.

One of the most mentioned obstacles considered by studies was accessibility to a suitable platform, like the internet, video, or hardware and software equipment. Furthermore, the lack of equality in internet access for all patients is another challenge (20). Hence, it seems that utilizing telemedicine on large scales for pandemics, like COVID-19, needs some infrastructure and considerations. Moreover, there is a need for further investment in the provision of communication infrastructures to ensure that everyone in the society has access to telemedicine services if needed. In addition, the lack of assessment or follow-up to achieve outcomes was another limitation of the reviewed studies.

As was explained in the results section, the majority of the studies were conducted on COVID-19 which is due to the need for rapid response to healthcare needs. Since there was not enough time for completing the assessment or follow-up phases in telemedicine projects, the implemented system has not been evaluated. Therefore, the effectiveness of the system is not clear and the results of the evaluation of some studies were not discussed in some projects $(18,21)$; however, their results will be available in the future.

Regarding the disease type, only one article was related to SARS infection, and no study was found about MERS disease. Nowadays, concerns are growing about preventing and managing COVID-19. Since human coronavirus is a contagious disease, the travel and transfer of the patients should be reduced. For this reason, telehealth and telemedicine have been successful in managing these diseases (13).

Regarding the objectives of the reviewed studies, the majority of them applied telemedicine to prevent people from unnecessarily visits to hospitals and clinics as well as hospitalization and also reduce the pressure on medical institutions (12). All of the authors of the reviewed studies 
believed that telemedicine is a valuable tool in controlling and managing patients with COVID-19 and can be helpful at the time of shortage in healthcare personnel (22).

The results of reviewed studies indicated that the application of telemedicine intervention is associated with a significant reduction in the risk of spreading the infection $(23,24)$. Regarding the application of telemedicine intervention, it can be applied to reduce the risk of transmission to both healthcare providers and patients, reduce the healthcare burden, and maintain appropriate patient care (18).

Researches have mentioned many advantages for using telemedicine in pandemics; nevertheless, the studies also had many limitations (such as lack of control group, small sample size, short time for telemedicine use, lack of assessment to achieve outcomes, and performance of the study in a single area). Due to these limitations, no definite comments can be given on the effectiveness of this technology. Therefore, to judge its effectiveness during a pandemic, we must wait for accurate evaluations of this technology.

The strengths of the present study included the lack of time constraints and usage of three important databases, which led to the maximum number of related articles and a review of papers presented at the conference. The limitation of this study was our review was limited to articles written in the English language.

\section{Conclusion}

This systematic review provides an overview of applying different telehealth techniques to control the coronavirus pandemic. This review showed that telemedicine services have the potential to meet healthcare needs without in-person visits during an epidemic by providing easy access to healthcare providers. This survey revealed that applying these approaches may have the capacity and potential for managing, monitoring, and treating COVID-19 patients. The use of telemedicine intervention allows the provision of high-quality care during anxious times without consuming excessive personal protective equipment or unnecessarily exposure of healthcare workers.

Due to the above-mentioned limitations of the reviewed studies (e.g., lack of control group, low sample size, lack of evaluation of the effect of telemedicine in some studies), it cannot be clearly stated whether telemedicine can be effective in this field. Examination of its impact requires more time and further studies. Utilizing technologies, such as sensors, mobile health, and the Internet of Things, alongside telemedicine can make it a key component of the healthcare system and help healthcare professionals and patients deal with COVID-19 disease.

\section{Acknowledgment}

Not applicable

\section{Footnotes}

Authors' Contributions: S.Saeedi, M.Gholamzadeh, S.Rezayi, and M.Tanhapour designed the systematic review and search strategy and also conducted database searches. S.Saeedi, M.Gholamzadeh, S.Rezayi, and M.Tanhapour conducted article screenings under the supervision of R.Safdari. S.Saeedi conducted the analysis and interpretation under the supervision of R.Safdari. S.Saeedi, M.Gholamzadeh, S.Rezayi, and M.Tanhapour drafted the manuscript. All authors reviewed the content and approved it.

Conflicts of Interest: The authors declare that they have no conflicts of interest.

Funding: The authors received no financial support for the research or publication of this article.

Ethical Considerations: The study involved only a review of literature without involving humans and/or animals. The authors have no ethical conflicts to disclose.

\section{References}

1. Fung TS, Liu DX. Human coronavirus: host-pathogen interaction. Ann Rev Microbiol. 2019;73:529-57. doi: 10.1146/annurev-micro-020518-115759. [PubMed: 31226023].

2. Channappanavar R, Perlman S. Pathogenic human coronavirus infections: causes and consequences of cytokine storm and immunopathology. Semin Immunopathol. 2017;39(5):529-39. doi: 10.1007/s00281-017-0629-x. [PubMed: 28466096].

3. Vabret A, Dina J, Gouarin S, Petitjean J, Corbet S, Freymuth F. Detection of the new human coronavirus HKU1: a report of 6 cases. Clin Infect Dis. 2006;42(5):634-9. doi: 10.1086/500136. [PubMed: 16447108].

4. Perlman S, Netland J. Coronaviruses post-SARS: update on replication and pathogenesis. Nat Rev Microbiol. 2009; 7(6):439-50. doi: 10.1038/nrmicro2147. [PubMed: 19430490].

5. Peiris J, Guan Y, Yuen K. Severe acute respiratory syndrome. Nat Med. 2004;10(12):S88-97. doi: 10.1038/nm1143. [PubMed: 15577937].

6. Chafekar A, Fielding BC. MERS-CoV: understanding the latest human coronavirus threat. Viruses. 2018;10(2):93. doi: 10.3390/v10020093. [PubMed: 29495250].

7. Marijon E, Karam N, Jost D, Perrot D, Frattini B, Derkenne C, et al. Out-of-hospital cardiac arrest during the COVID-19 pandemic in Paris, France: a population-based, observational study. Lancet Public Health. 2020;5(8):e437-43. doi: 10.1016/S2468-2667(20)30117-1. [PubMed: 32473113].

8. Yang K, Sheng Y, Huang C, Jin Y, Xiong N, Jiang K, et al. Clinical characteristics, outcomes, and risk factors for mortality in patients with cancer and COVID-19 in Hubei, China: a multicentre, retrospective, cohort study. Lancet Oncol. 2020;21(7):904-13. doi: 10.1016/S1470-2045(20)30310-7. [PubMed: 32479787].

9. World Health Organization. Coronavirus disease (COVID-19) pandemic. Geneva: World Health Organization; 2020.

10. Wang L, Wang Y, Ye D, Liu Q. Erratum to "A review of the 2019 Novel Coronavirus (COVID-19) based on current evidence" [International Journal of Antimicrobial Agents 55/6 (2020) 105948]. Int J Antimicrob Agents. 2020;56(3):106137. doi: 10.1016/j.ijantimicag.2020.106137. [PubMed: 32826129].

11. Smith AC, Thomas E, Snoswell CL, Haydon H, Mehrotra A, 
Clemensen J, et al. Telehealth for global emergencies: Implications for coronavirus disease 2019 (COVID-19). J Telemed Telecare. 2020;26(5):309-13. doi: 10.1177/1357633X20916567. [PubMed: 32196391].

12. Gao Y, Liu R, Zhou Q, Wang X, Huang L, Shi Q, et al. Application of telemedicine during the coronavirus disease epidemics: a rapid review and meta-analysis. Ann Transl Med. 2020; 8(10):626. doi: 10.21037/atm-20-3315. [PubMed: 32566563].

13. Keshvardoost S, Bahaadinbeigy K, Fatehi F. Role of telehealth in the management of COVID-19: lessons learned from previous SARS, MERS, and ebola outbreaks. Telemed J E Health. 2020;26(7):850-2. doi: 10.1089/tmj.2020.0105. [PubMed: 32329659].

14. Moher D, Liberati A, Tetzlaff J, Altman DG, PRISMA Group. Preferred reporting items for systematic reviews and metaanalyses: the PRISMA statement. PLoS Med. 2009;6(7): e1000097. doi: 10.1371/journal.pmed.1000097. [PubMed: 19621072].

15. Meinert E, Milne-Ives M, Surodina S, Lam C. Agile requirements engineering and software planning for a digital health platform to engage the effects of isolation caused by social distancing: case study. JMIR Public Health Surveill. 2020;6(2):e19297. doi: 10.2196/19297. [PubMed: 32348293].

16. O'Brien M, McNicholas F. The use of telepsychiatry during COVID-19 and beyond. Ir J Psychol Med. 2020;37(4):250-5. doi: 10.1017/ipm.2020.54. [PubMed: 32434596].

17. Annis T, Pleasants S, Hultman G, Lindemann E, Thompson JA, Billecke S, et al. Rapid implementation of a COVID-19 remote patient monitoring program. $\mathrm{J} \mathrm{Am}$ Med Inform Assoc. 2020;27(8):1326-30. doi: 10.1093/jamia/ocaa097. [PubMed: 32392280].

18. Borchert A, Baumgarten L, Dalela D, Jamil M, Budzyn J, Kovacevic N, et al. Managing urology consultations during COVID-19 pandemic: application of a structured care pathway. Urology. 2020;141:7-11. doi: 10.1016/j.urology.2020.04.059. [PubMed: 32330531].

19. Mehraeen E, Hayati B, Saeidi S, Heydari M, Seyedalinaghi S. Self-care instructions for people not requiring hospitalization for coronavirus disease 2019 (COVID-19). Arch Clin Infect Dis. 2020;15(COVID-19):e102978. doi: 10.5812/archcid.102978.

20. Blackhall KK, Downie IP, Ramchandani P, Kusanale A, Walsh S, Srinivasan B, et al. Provision of emergency maxillofacial service during the COVID-19 pandemic: a collaborative five centre UK study. Br J Oral Maxillofac Surg. 2020;58(6):698703. doi: 10.1016/j.bjoms.2020.05.020. [PubMed: 32482348].

21. Denis F, Galmiche S, Dinh A, Fontanet A, Scherpereel A, Benezit $\mathrm{F}$, et al. Epidemiological observations on the association between anosmia and COVID-19 infection: analysis of data from a self-assessment web application. J Med Internet Res. 2020;22(6):e19855. doi: 10.2196/19855. [PubMed: 32496206].

22. Mann DM, Chen J, Chunara R, Testa PA, Nov O. COVID-19 transforms health care through telemedicine: evidence from the field. J Am Med Inform Assoc. 2020;27(7):1132-5. doi: 10.1093/jamia/ocaa072. [PubMed: 32324855].

23. Bonavita S, Tedeschi G, Atreja A, Lavorgna L. Digital triage for people with multiple sclerosis in the age of COVID-19 pandemic. Neurol Sci. 2020;41(5):1007-9. doi: 10.1007/s10072-020-04391-9. [PubMed: 32303856].

24. Evans KD, Yang Q, Liu Y, Ye R, Peng C. Sonography of the lungs: diagnosis and surveillance of patients with COVID-19. J Diagn Med Sonogr. 2020;36(4):370-6. doi: 10.1177/8756479320917107.

25. Timmers T, Janssen L, Stohr J, Murk JL, Berrevoets MAH. Using eHealth to support COVID-19 education, self-assessment, and symptom monitoring in the Netherlands: observational study. JMIR Mhealth Uhealth. 2020;8(6):e19822. doi: 10.2196/19822. [PubMed: 32516750].

26. Jethwa T, Ton A, Paredes Molina CS, Speicher L, Walsh K, Knight D, et al. Establishing mayo clinic's coronavirus disease 2019 virtual clinic: a preliminary communication. Telemed J E Health. 2020;26(11):1419-23. doi: 10.1089/tmj.2020.0145. [PubMed: 32516070].

27. Rabunal R, Suarez-Gil R, Golpe R, Martinez-Garcia M, GomezMendez R, Romay-Lema E, et al. Usefulness of a Telemedicine Tool TELEA in the Management of the COVID-19 Pandemic. Telemed J E Health. 2020; 26(11):1332-35. doi: 10.1089/tmj.2020.0144. [PubMed: 32501747].

28. Tran DL, Lai SR, Salah RY, Wong AY, Bryon JN, McKenna MC, et al. Rapid de-escalation and triaging patients in communitybased palliative care. J Pain Symptom Manag. 2020;60(1): e45-7. doi: 10.1016/j.jpainsymman.2020.03.040. [PubMed: 32276099].

29. Zhang JG, Sun JY, Yang YY, Chen XM, Meng LL, Lian P. Webbased electronic patient records for collaborative medical applications. Comput Med Imaging Graph. 2005;29(2-3):11524. doi: 10.1016/j.compmedimag.2004.09.005. [PubMed: 15755531].

30. Schinkothe T, Gabri MR, Mitterer M, Gouveia P, Heinemann V, Harbeck N, et al. A web- and app-based connected care solution for COVID-19 in- and outpatient care: qualitative study and application development. JMIR Public Health Surveill. 2020;6(2):e19033. doi: 10.2196/19033. [PubMed: 32406855].

31. Krausz M, Westenberg JN, Vigo D, Spence RT, Ramsey D. Emergency response to COVID-19 in Canada: platform development and implementation for ehealth in crisis management. JMIR Public Health Surveill. 2020;6(2):e18995. doi: 10.2196/18995. [PubMed: 32401218].

32. Smith WR, Atala AJ, Terlecki RP, Kelly EE, Matthews CA. Implementation guide for rapid integration of an outpatient telemedicine program during the COVID-19 pandemic. J Am Coll Surg. 2020;23(2):216-22. doi: 10.1016/j.jamcollsurg.2020.04.030. [PubMed: 32360960].

33. Grange ES, Neil EJ, Stoffel M, Singh AP, Tseng E, RescoSummers K, et al. Responding to COVID-19: the UW medicine information technology services experience. Appl Clin Inform. 2020;11(2):265-75. doi: 10.1055/s-0040-1709715. [PubMed: 32268390].

34. Khairat S, Meng C, Xu Y, Edson B, Gianforcaro R. Interpreting COVID-19 and virtual care trends: cohort study. JMIR Public Health Surveill. 2020;6(2):e18811. doi: 10.2196/18811. [PubMed: 32252023].

35. Gong K, Xu Z, Cai Z, Chen Y, Wang Z. Internet hospitals help prevent and control the epidemic of COVID-19 in China: multicenter user profiling study. J Med Internet Res. 2020;22(4):e18908. doi: 10.2196/18908. [PubMed: 32250962]. 